\title{
Can conservation incentives promote willingness to coexist with large carnivores in the eastern Serengeti ecosystem?
}

\author{
Franco P. Mbise ${ }^{1^{\star}}$ and Eivin Røskaft ${ }^{2}$ \\ ${ }^{1}$ Department of Biology, University of Dodoma, Dodoma, Tanzania. \\ ${ }^{2}$ Department of Biology, Norwegian University of Science and Technology, Trondheim, Norway.
}

Received 23 April, 2021; Accepted 24 June, 2021

\begin{abstract}
Communities living adjacent to protected areas tend to express more willingness to coexist with large carnivores in their areas when they receive tangible benefits. The aim of this study was to explore people's willingness to coexist with large carnivores, including lions (Panthera leo), leopards (Panthera pardus), cheetahs (Acinonyx jubatus), spotted hyenas (Crocuta crocuta), African wild dogs (Lycaon pictus) and black-backed jackals (Canis mesomelas schmidti). The authors used a pre-test and posttest approach by implementing a chemoprophylactic program as a conservation incentive among the Maasai and Sonjo tribes living in the eastern Serengeti, Tanzania. Chemoprophylaxis is the prevention of infectious disease by using chemical agents. The pre-test results showed that both tribes had low willingness to coexist with these large carnivores. Of the two tribes, the Sonjo tribe was less willing than the Maasai tribe. Our post-test results indicated an increase in willingness to coexist with large carnivores in their area because the livestock loss due to large carnivore depredation was significantly lower than that caused by diseases in both tribes. Therefore, this study calls for more conservation incentives to local people to promote their willingness to coexist with large carnivores in their areas.
\end{abstract}

Key words: Coexistence, depredation, diseases, large carnivores, livestock, Maasai and Sonjo tribes.

\section{INTRODUCTION}

Coexistence between humans and carnivores is only possible (Carter and Linnell, 2016) if both biological and social strategies are used wisely to curb conflict (Redpath et al., 2013; Treves and Karanth, 2003) and thereby reduce carnivore mortality (Treves and Karanth, 2003). According to Carter and Linnell (2016), coexistence is the "dynamic but sustainable state in which humans and large carnivores co-adapt to living in shared landscapes where human interactions with carnivores are governed by effective institutions that ensure long-term carnivore population persistence, social legitimacy, and tolerable levels of risk". Aiming for coexistence is the way forward to reduce human-carnivore conflict, which in turn will save carnivores in the future (Dickman, 2010; Woodroffe et al., 2005).

Many protected areas in Africa are facing great

*Corresponding author. E-mail: francombise@gmail.com. 
challenges, and the areas adjacent to their borders pose a serious threat to large carnivores and other species (Caro et al., 2013). The main target for conservation stakeholders in Tanzania is reduction of the decrease in the carnivore population adjacent to many networks of protected areas. The edges of protected areas are gradually shrinking due to human population increase, resulting in increased demand for land for settlement and farming. Such demands tend to encroach on arable and fertile lands adjacent to protected areas, which negatively impacts the conservation of carnivores and other wildlife species (Shivik 2006; Nyhus and Ronald, 2010). In rural areas, especially those close to protected areas, land for livestock husbandry is open access, which attracts pastoralists to such places. Most people in Africa live in rural areas and there are many trade-offs encountered by people living adjacent to protected areas. The livelihoods of such societies have been compromised due to the costs associated with wildlife interactions (Adams and Hutton, 2007; Nana and Tchamadeu, 2014; Vedeld et al., 2012). Thus, people living adjacent to protected areas tend to have negative attitudes towards wildlife as they impact their livelihoods negatively (Dickman et al., 2014; Romanach et al., 2007; Røskaft et al., 2007).

Previous studies have revealed that once these conservation conflicts are managed, negative impacts on biodiversity are reduced as well (Lagendijk and Gusset, 2008; Redpath et al., 2013; Vedeld et al., 2012; Woodroffe et al., 2005). The management of conflicts between people and carnivores will cultivate positive attitudes, which in turn will enhance conservation initiatives (Conover, 2002). This observation also supports findings that people affected by large carnivores through human attacks and livestock depredation normally express negative attitudes and revenge by killing the carnivores using either poison and/or snares (Abade et al., 2014; Dar et al., 2009; Hazzah, 2006; Linnell et al., 2001; Romañach et al., 2007).

Despite human population growth causing carnivore habitats to shrink, measures should be taken to merge both human activities and carnivore conservation (Treves and Karanth, 2003). If efficient management practices are implemented, coexistence between people and predators can be enhanced (Linnell et al., 2001). Livestock depredation in rural areas is the main cause of humancarnivore conflict. Consolation programs should be implemented to help the victims realize tangible benefits from to the presence of carnivores (Breitenmoser, 1998; Skonhoft, 1998). It has been found that implementing conservation incentives such as a chemoprophylactic program improves coexistence between humans and large carnivores (CDPNews, 2003). Chemoprophylaxis is the prevention of infectious disease by using chemical agents to boost livestock immunity (Jibbo et al., 2010). If local people are satisfied with conservation incentives, their conflicts with carnivores may be reduced.

Therefore, understanding local communities' attitudes towards carnivores is necessary in conservation planning. When attitudes are positive towards large carnivores, people are more willing to coexist with these animals, which contributes to their conservation (Hazzah, 2006). For instance, African lion populations are declining due to the negative attitudes of local communities living in proximity to these species and the resulting actions (Dickman, 2017). Thus, promoting and motivating local communities to increase their willingness to coexist with large carnivores will enhance their conservation initiative (Dickman et al., 2014).

The overall aim of this study was to test whether people's willingness to coexist with large carnivores would change after the implementation of a chemoprophylactic program. In testing, we had two hypotheses: (1) Livestock diseases are the main contributing factor to livestock loss and cause more deaths than carnivore depredation among the livestock of the Maasai and Sonjo tribes, and (2) therefore, the implementation of a chemoprophylactic program would be of paramount importance to these communities because it would reduce livestock losses, which would be expected to improve tolerance towards large carnivores.

\section{MATERIAL AND METHODS}

\section{Study area}

The study was conducted in the Eastern Serengeti ecosystem, Tanzania, and all surveyed villages were located in the Loliondo Game Controlled Area (LGCA) (Mbise et al., 2018, 2020). The Maasai tribe lives inside the LGCA, and the Sonjo tribe lives on the eastern border of this area. Administratively, the LGCA is under the Ngorongoro District Council (MNRT, 2013) and covers approximately $4500 \mathrm{~km}^{2}$ (Lyamuya et al., 2016).

The LGCA is bordered by Serengeti National Park to the west, Ngorongoro Conservation Area to the south, Kenya to the north, and Lake Natron to the east (Lyamuya et al., 2016; Masenga and Mentzel, 2005). The LGCA has a rich diversity of ungulate species, including wildebeest (Connochaetes taurinus), zebra (Equus burchelli), impala (Aepyceros melampus), Grant's gazelle (Nanger granti), and Thomson's gazelle (Eudorcas thomsonii), which occur sympatrically with humans. The famous Serengeti-Mara wildebeest migration passes through parts of the LGCA. The area has all five large carnivore species: lions (Panthera leo), leopards (Panthera pardus), cheetahs (Acinonyx jubatus), spotted hyenas (Crocuta crocuta), and African wild dogs (Lycaon pictus) (Holdo et al., 2010; Maddox, 2003). The Maasai and the Sonjo tribes experience significant livestock losses to large carnivores and diseases (Lyamuya et al., 2016). The authors collected data from six villages: three Maasai tribes (Ololosokwan, Soitsambu and Oloipiri) and three Sonjo tribes (Yasimdito, Samunge and Sale) (Figure 1). The Maasai tribe are pastoralists, while the Sonjo tribe are agropastoralists (Masenga and Mentzel, 2005).

\section{Data collection}

Data were collected in September 2016 and again in February 2017 using a pre-test and post-test questionnaire survey. The study villages were randomly selected; three from each tribe (the Maasai and Sonjo). In September 2016, the survey of people's willingness 


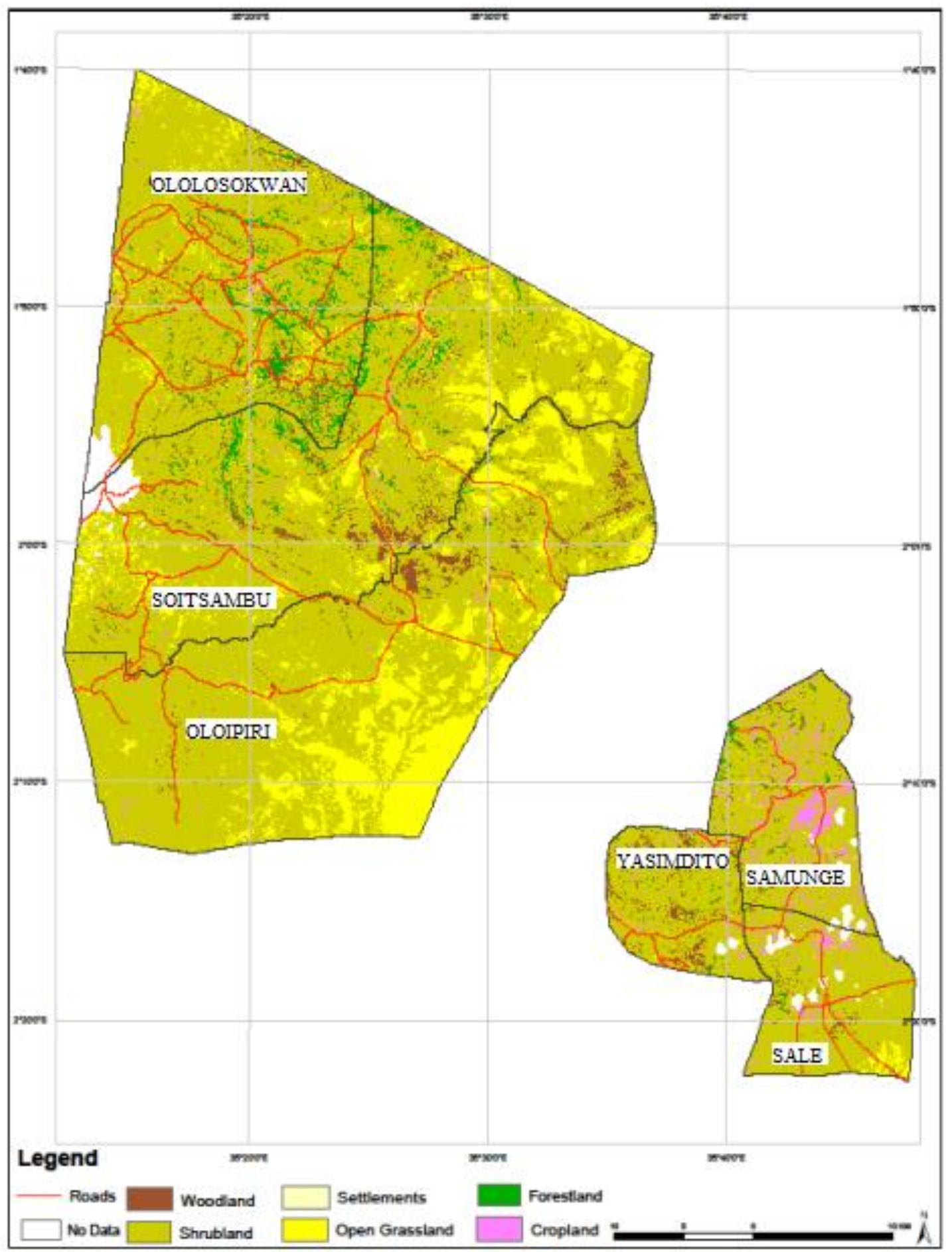

Figure 1. Map showing the study villages of Ololosokwan, Soitsambu, Oloipiri, Samunge, Sale, and Yasimdito in the Eastern Serengeti ecosystem.

to coexist with large carnivores was carried out as the pre-test with the aim of gathering responses from the Maasai and Sonjo tribes before the conservation incentive (chemoprophylactic program) was introduced. The people's willingness to coexist with large carnivores was assessed in an open way to determine whether the responses were positive, neutral, or negative. The question asked, "Will conservation incentives be helpful to motivate your willingness to coexist with large carnivores?". The question assessed the respondents' willingness to coexist with large carnivores in their area based on whether they agreed that conservation incentives promote willingness to overlook livestock loss due to depredation by large carnivores (positive), whether the respondents disagreed 
Table 1. Dependent and independent variables used before and after implementing conservation incentive.

\begin{tabular}{lllcc}
\hline Variable & & N & $\%$ \\
\hline \multirow{4}{*}{ Dependent variable } & Negative & 89 & 74.2 \\
& \multirow{3}{*}{ Before incentive } & Neutral & 23 & 19.2 \\
& & Positive & 8 & 6.7 \\
& \multirow{4}{*}{ After incentive } & Negative & 23 & 19.2 \\
& & Neutral & 9 & 7.5 \\
& & Positive & 88 & 73.3 \\
& & Maasai & 60 & 50 \\
Independent & Tribe & Sonjo & 60 & 50 \\
variables & \multirow{4}{*}{ Age } & $18-35$ & 41 & 34.2 \\
& & $36-49$ & 47 & 39.2 \\
& & $>50$ & 32 & 26.7 \\
& \multirow{2}{*}{ Education } & No & 35 & 29.2 \\
& & Primary & 71 & 59.2 \\
& & Secondary & 14 & 11.7 \\
\hline
\end{tabular}

on the issue (negative) and whether the respondents had no opinion regarding the two ideas (neutral). To avoid influencing the respondents' answers, we did not mention what incentive would come next. In conjunction with this question, we also recorded the reported number of livestock losses for the last two years (2015 and 2016) caused by large carnivores and diseases.

Common diseases in the area were coenurosis, East Coast fever (ECF), Contagious Bovine Pleuropneumonia (CBPP), and anthrax. However, in the chemoprophylactic program we targeted helminths infestation and tick-borne haemoparasites especially ECF. ECF is caused by Theileria parva from infected ticks (Rhipicephalus appendiculatus). ECF affects lymph nodes first and then spreads to the red blood cells, resulting in severe lung edema and finally death (Gilioli et al., 2009; Kivaria, 2007). Coenurosis is a common neurological disease for both goats and sheep caused by tapeworms of the genus Taenia multiceps. The cyst is transmitted when infected domestic animals and large carnivores contaminate pastures with their feces. The infective Coenurus cerebralis cysts are then swallowed by sheep and goats (Scala and Varcasia, 2006; Sharma and Chauhan, 2006). CBPP is transmitted by infective aerosol inhalation of Mycoplasma mycoides mycoides (Almaw et al., 2016; Scott, 2014). Anthrax is a zoonotic disease caused by the Bacillus anthracis bacterium, which can be transmitted to humans through the consumption of infected carcasses or by handling infected animal products. The bacterium has no animal reservoir but is an environmental bacterium that exists in spore form in the environment and in vegetative form in infected animals, and the disease affects all warm-blooded animals, both wild and domestic (Hugh-Jones, 2014; Smith et al., 1999).

After four months (February 2017), a post-test survey was carried out at the same time that chemoprophylaxis was given to the livestock of our previous respondents. The chemoprophylactic program exercise was administered by a Tanzania Wildlife Research Institute (TAWIRI) veterinary officer. We administered two sets of drugs: (1) oxytetracycline hydrochloride $20 \%$, a long acting antibiotic against a wide range of gram-positive and gram-negative bacteria and other microorganisms, such as Mycoplasma pneumoniae, Coxiella burnetti and Plasmodium spp.; and (2) albendazole $10 \%$, a broad spectrum anthelminthic for the prophylaxis and treatment of immature and mature infectious gastrointestinal nematodes, lung worms, tape worms and trematodes.
During February, due to drought, some respondents moved their livestock to other villages, so our sample size dropped from 180 to 120 respondents. We asked the same question about their willingness to coexist with large carnivores if they received conservation incentives that was asked previously. In the Maasai and Sonjo tribes, only men have a right of say, so we had more male participants than female (Table 1) (Mbise et al., 2018). Therefore, it is a challenge to acquire an equal number of males and females, and doing so requires additional time in the field (Mbise et al., 2018). Age categories were split into three groups (youth $=18-35$ years, adult $=36-49$ years, and elderly $=$ above 50 years). Most of the respondents belonged to the adult group (Table 1). Most of the respondents had a primary education (Table 1 ), and all the respondents were either from the Maasai or Sonjo tribes (Table 1).

\section{Data analyses}

They used SPSS version 24 for data analyses (IBM, 2016), which included Kruskal-Wallis tests, paired samples t-tests (Table 6), oneway ANOVA tests (Table 7) and chi-square tests. Kruskal-Wallis test was used to determine the predictor variable that explained most of the variation in people's willingness to coexist with large carnivores (Table 1). Paired t-tests were used to assess potential changes in people's willingness to coexist with large carnivores in both tribes. A one-way ANOVA test was used to explain the differences in livestock losses due to diseases and depredation. The chi-square test was used to explain disease frequency differences between the two tribes. The data were tested for normality, and the $p$-value was set to below 0.05 .

\section{RESULTS}

\section{People's willingness to coexist with large carnivores before implementing the conservation incentive}

The authors used a Kruskal-Wallis test to assess the variation in the people's willingness to coexist with large 
Table 2. A Kruskal-Wallis test to assess the variation in the people's willingness to coexist with large carnivores before implementing the chemoprophylactic program.

\begin{tabular}{lccc}
\hline Variable & Chi-square & df & P-value \\
\hline Tribe & 12.900 & 2 & 0.002 \\
Age & 1.053 & 2 & 0.591 \\
Education & 1.172 & 2 & 0.557 \\
\hline
\end{tabular}

Table 3. People's willingness to coexist with large carnivores before the chemoprophylactic program.

\begin{tabular}{lcccccc}
\hline \multirow{2}{*}{ Tribe } & \multicolumn{2}{c}{ Positive } & \multicolumn{2}{c}{ Neutral } & \multicolumn{2}{c}{ Negative } \\
\cline { 2 - 7 } & $\mathbf{N}$ & $\%$ & $\mathbf{N}$ & $\%$ & $\mathbf{N}$ & $\%$ \\
\hline Maasai tribe & 7 & 10 & 17 & 30 & 36 & 60 \\
Sonjo tribe & 1 & 1.7 & 6 & 10 & 53 & 88.3 \\
\hline
\end{tabular}

Table 4. A Kruskal-Wallis test analysis to assess the variation in the people's willingness to coexist with large carnivores after implementing the chemoprophylactic program.

\begin{tabular}{lccc}
\hline Variable & Chi-square & df & P-value \\
\hline Tribe & 28.373 & 2 & 0.000 \\
Age & 1.971 & 2 & 0.373 \\
Education & 0.777 & 2 & 0.678 \\
\hline
\end{tabular}

carnivores before implementing the chemoprophylactic program (positive, neutral, and negative) as a dependent variable towards three independent variables (tribe, age and education) (Table 2).

Tribe was the only predictor variable explaining this variation in the people's willingness to coexist with large carnivores. Both tribes had lower willingness to coexist with large carnivores, although the Sonjo tribe was less willing than the Maasai tribe (Pearson $\mathrm{X}^{2}=14.338, \mathrm{df}=2$, $\mathrm{p}<0.0001$; Table 3).

\section{People's willingness to coexist with large carnivores after implementation of the conservation incentive}

To explain the variation in the people's willingness to coexist with large carnivores after implementation of the chemoprophylactic program (positive, neutral, and negative), we tested three independent variables (tribe, age and education) using Kruskal-Wallis test (Table 4).

Tribe was the most explanatory variable to explain this variation in the people's willingness to coexist with large carnivores, with the Maasai tribe's willingness being higher than that of the Sonjo tribe (Pearson $x^{2}=37.833$, $\mathrm{df}=2, \mathrm{p}<0.0001$; Table 5). The willingness to coexist with large carnivores increased in both tribes after the conservation incentive was implemented (Maasai: Paired samples t-test, $\mathrm{t}=7.812, \mathrm{df}=59, \mathrm{p}<0.0001$; Sonjo:
Paired samples t-test, $t=15.108, d f=59, p<0.0001)$ (Table 5).

\section{Major factors contributing to livestock losses}

The results revealed that the number of livestock losses due to large carnivore depredation was significantly lower than the number caused by diseases in both tribes (Maasai: $\mathrm{t}=-5.373$, $\mathrm{df}=3$ and $59, \mathrm{p}<0.0001$; Sonjo: $\mathrm{t}=-$ 7.820, $\mathrm{df}=3$ and 59, $\mathrm{p}<0.0001$ ) (Table 6). Goats and sheep were significantly more prone to diseases than cattle in both tribes $(\mathrm{F}=34.89$, $\mathrm{df}=1$ and $118, \mathrm{p}<$ $0.0001)$ and $(F=25.79$, df $=1$ and $118, p<0.0001)$, respectively. Additionally, predators killed significantly more goats and sheep than cattle $(F=9.47, \mathrm{df}=1$ and $118, p=0.003),(F=9.16$, df $=1$ and $118, p=0.009)$, and $(F=20.59$, df $=1$ and $118, p<0.0001)$, respectively (Table 6).

East Coast Fever and Contagious Bovine Pleuropneumonia were the most common diseases causing cattle loss in the Maasai and the Sonjo tribes, respectively; however, the difference between the two tribes was not statistically significant (Pearson $x^{2}=1.427$, $\mathrm{df}=2, \mathrm{p}=0.49$; Table 7). Goats and sheep were more affected by coenurosis than by anthrax, and East Coast Fever, with no differences between the two tribes (Pearson $x^{2}=0.962, d f=2, p=0.81$; Table 7). 
Table 5. People's willingness to coexist with large carnivores after the chemoprophylactic program.

\begin{tabular}{lcccccc}
\hline \multirow{2}{*}{ Tribe } & \multicolumn{2}{c}{ Positive } & \multicolumn{2}{c}{ Neutral } & \multicolumn{2}{c}{ Negative } \\
\cline { 2 - 7 } & $\mathbf{N}$ & $\%$ & $\mathbf{N}$ & $\%$ & $\mathbf{N}$ & $\%$ \\
\hline Maasai tribe & 55 & 91.7 & 5 & 8.3 & 0 & 0 \\
Sonjo tribe & 33 & 55 & 4 & 6.7 & 23 & 38.3 \\
\hline
\end{tabular}

Table 6. Comparison of livestock losses related to diseases and carnivore depredation in the Maasai and Sonjo tribes.

\begin{tabular}{cccccccc}
\hline \multirow{2}{*}{ Tribe } & \multirow{2}{*}{ Variable } & \multicolumn{2}{c}{ Livestock loss - diseases } & \multicolumn{5}{c}{ Depredation } \\
\cline { 3 - 8 } & & Cattle & Goats & Sheep & Cattle & Goats & Sheep \\
\hline \multirow{2}{*}{ Maasai tribe } & Mean & 12.7 & 25.8 & 20.7 & 2.5 & 3.2 & 14.7 \\
& Std. & 15.4 & 21.1 & 16.5 & 1.9 & 2.5 & 13 \\
\multirow{2}{*}{ Sonjo tribe } & Mean & 5.9 & 10.4 & 6.7 & 1.6 & 1.5 & 1.6 \\
& Std. & 5.7 & 8.8 & 6.6 & 1 & 0.8 & 2.7 \\
\hline
\end{tabular}

\section{DISCUSSION}

This study's findings give insight into what can be done for communities living in the same landscape as large carnivores, as is the case in the eastern Serengeti ecosystem, by providing cost-effective and tangible benefits to the local people who bear most of the conservation costs. This applies strongly in developing countries, especially in Africa, where many governments do not have the full potential to compensate people for the loss of their livestock to predators. In the Maasai and Sonjo tribes in the eastern Serengeti ecosystem, disease was more likely to cause livestock loss than depredation by carnivores. Exploring alternatives for promoting willingness to tolerate depredation, treating livestock against disease presents one of the option for producing harmonic coexistence between people and predators, especially in these two tribes. However, this alternative option must be implemented with caution as in a longterm will increase the livestock number which ultimately decreases wild prey, increases the rate of depredation, conflict, and retaliation.

\section{People's willingness to coexist with large carnivores before and after the implementation of a conservation incentive}

This study revealed that the Maasai tribe was more willing to coexist with large carnivores than the Sonjo tribe if their livestock were treated against diseases, which represent a much greater cause of livestock loss than large carnivore depredation. The Sonjo tribe members were more rigid in their attitude toward coexist with large carnivores in their area, even after receiving a conservation incentive. According to previous studies by Bencin et al. (2016) and Hazzah et al. (2017), for the better conservation of carnivore species, efforts should be dedicated to influencing human behavior to realize and appreciate the benefits (ecologically and economically) of large carnivores. Currently, financial compensation after livestock depredation loss is not necessarily an effective and sustainable tool for carnivore conservation (CDPNews, 2003; Naughton-Treves et al., 2003).

To explore alternatives, this study tested people's willingness to coexist with large carnivores before and after the implementation of a chemoprophylactic program, which serves as an alternative conservation incentive. The program was positively received because the Maasai and Sonjo communities lose more livestock to diseases than depredation. Many respondents indicated that they were willing to lose livestock to depredation because the rates of depredation are low. Diseaserelated livestock loss was three times higher for the Maasai tribe and five times for the Sonjo tribe than depredation; therefore, getting a sustainable program to treat livestock against diseases will promote willingness for coexisting with large carnivores.

Most communities living adjacent to or inside-protected areas are less willing to coexist with large carnivores (Spira, 2014). Policy makers and researchers have a challenge of addressing a long history of conflict (Kideghesho et al., 2007). If communities realize a tangible benefit, direct or indirect, due to the presence of carnivores, the probability of sustainable coexistence will be improved (Bencin et al., 2016; Newmark et al., 1993). When conservation incentives are provided to such communities, they enhance positive behavior and perceptions towards carnivores in the vicinity (Lagendijk and Gusset, 2008; Smith, 2005).

These communities bear the costs of carnivore conservation, and thus, in the long term, a sense of ownership is cultivated when tangible benefits are 
Table 7. Cattle, goat, and sheep losses due to different diseases.

\begin{tabular}{lcccccccc}
\hline \multirow{2}{*}{ Tribe } & \multicolumn{2}{c}{ Diseases-cattle } & \multicolumn{3}{c}{ Diseases-goats } & Diseases-sheep & \\
\cline { 2 - 9 } & Anthrax & CBPP & ECF & Coenurosis & Anthrax & Coenurosis & Anthrax & ECF \\
\hline Maasai & 5 & 18 & 25 & 46 & 13 & 29 & 13 & 15 \\
$\%$ & 10.4 & 37.5 & 52.1 & 78 & 22 & 50.9 & 22.8 & 26.3 \\
Sonjo & 4 & 8 & 8 & 37 & 14 & 20 & 13 & 10 \\
$\%$ & 20 & 40 & 40 & 72.5 & 27.5 & 46.5 & 30.2 & 23.3 \\
\hline
\end{tabular}

realized, which ultimately tends to reduce the existing human-carnivore conflict (Kidegesho, 2008; Newmark et al., 1993). Tangible benefits tend to improve the tolerance level of the costs of large carnivores (Lagendijk and Gusset, 2008). For the coexistence of people and carnivores, it is imperative to minimize existing humancarnivore conflicts, such as livestock depredation (Lyamuya et al., 2014; Mbise et al., 2018; Newmark et al., 1993; Nyahongo and Røskaft, 2012).

\section{Major factors contributing to livestock losses}

In many savannah ecosystems, pastoralists live together with large carnivores, and the main threat of livestock loss is diseases, followed by depredation (Nyahongo and Røskaft, 2012). When large carnivores co-occur with livestock in the same landscape the likelihood of livestock depredation is higher (Mbise et al., 2018; Spira, 2014). Loss from diseases and depredation negatively impacts the livelihoods of the communities experiencing such problems (Gifford-Gonzalez, 2000; Nyahongo and Røskaft, 2012). The effective control of diseases with multi-host pathogens is complex (Lembo et al., 2008); however, if communities with livestock are given proper awareness of disease control and prevention, they can minimize the disease severity in their areas.

In the tropics, the prevalence of diseases that affect livestock is the major cause of income loss. Most of the pastoral communities depend on livestock for their survival (Gifford-Gonzalez, 2000). Different measures are available to treat livestock, such as chemoprophylaxis, which boosts immunity against diseases (Jibbo et al., 2010). However, in developing countries, due to a lack of disease awareness, livestock are untreated with disease prevention measures (Nyahongo and Røskaft, 2012). Most communities have a large number of livestock with suboptimal health. Large livestock herds are a sign of wealth and prestige in both the Maasai and the Sonjo communities (Hodgson, 2011). Thus, there is a need for increased awareness of the benefits of selling a few animals to buy drugs to treat the rest, as many pastoralists have no formal education to inform important life decisions.

Additionally, awareness of diseases is very important for these communities because some diseases that affect livestock are relatively simple to prevent and control if the community is well educated. For instance, during the authors chemoprophylactic program, they found that many sheep and goats were dying because of coenurosis disease. If these communities implement veterinary guidelines such as deworming domestic dogs and providing chemoprophylaxis for livestock, the longexisting problem of livestock loss due to diseases will decline. Furthermore, a compliment was given to the chemoprophylactic program for the healthy progress of all the livestock that received chemoprophylaxis. Most of the livestock were in poor condition due to drought and thus were susceptible to diseases.

This study is among few studies that have tested how conservation incentives can change people's willingness to coexist with large carnivores before and after implementing the chemoprophylactic program. Both hypotheses were supported by our findings. First, disease is responsible for more livestock losses than carnivore depredation; therefore, treating livestock against diseases will improve tolerance of depredation loss. Second, people's willingness to coexist with large carnivores increased after the implementation of the chemoprophylactic program.

\section{Conclusion}

The harmonic coexistence between humans and large carnivores goes hand in hand with providing tangible benefits to the communities living with these species. Treating the livestock of these two tribes against diseases will provide tangible benefits that will justify the costs incurred from living with large carnivores in their areas. Additionally, the Tanzanian wildlife policy can integrate this element by providing tangible benefits to communities living side by side with large carnivores in order to change people's negative attitudes to more positive attitudes towards carnivores. Although livestock losses caused by disease in the Maasai and Sonjo tribes are higher than the losses caused by depredation, there is a need to improve livestock safeguarding measures coupled with tangible benefits to the local people such as treating their livestock against diseases. If both types of measures are applied wisely, there is a promising goal of improving people's willingness to coexist with wild 
carnivores in the area.

\section{CONFLICT OF INTERESTS}

The authors have not declared any conflict of interests.

\section{REFERENCES}

Abade L, Macdonald DW, Dickman AJ (2014). Assessing the relative importance of landscape and husbandry factors in determining large carnivore depredation risk in Tanzania's Ruaha landscape. Biological Conservation 180:241-248.

Adams WM, Hutton J (2007). People, parks and poverty: Political ecology and biodiversity conservation. Conservation and Society 5(2):147-183.

Almaw G, Duguma M, Wubetie A, Tuli G, Koran T (2016). A contagious bovine pleuropneumonia outbreak on a research farm in Ethiopia, and its dynamics over an eight-month period. OIE Revue Scientifique et Technique 35(3):787-793.

Bencin H, Kioko J, Kiffner C (2016). Local people's perceptions of wildlife species in two distinct landscapes of Northern Tanzania. Nature Conservation 34:82-92.

Breitenmoser U (1998). Large predators in the Alps: The fall and rise of man's competitors. Biological Conservation 83(3):279-289.

Caro T, Elisa M, Gara J, Kadomo D, Martin A, Mushi D, Timbuka C (2013). Integrating research with management: the case of Katavi National Park, Tanzania. African Zoology 48:1-12.

Carter NH, Linnell JD (2016). Co-Adaptation Is Key to Coexisting with Large Carnivores. Trends in Ecology and Evolution 31(8):575-578.

CDPNews (2003). Carnivore Damage Prevention News. A Large Carnivore Initiative for Europe 6:1-20.

Conover M (2002). Resolving human-wildlife conflicts. The science of wildlife damage management. CRC Press, Boca Raton, Florida, USA, $418 \mathrm{pp}$.

Dar NI, Minhas RA, Zaman Q, Linkie M (2009). Predicting the patterns, perceptions and causes of human-carnivore conflict in and around Machiara National Park, Pakistan. Biological Conservation 142(10):2076-2082.

Dickman A (2010). Complexities of conflict: the importance of considering social factors for effectively resolving human-wildlife conflict. Animal Conservation 13(5):458-466.

Dickman A (2017). The biggest threat to African lions isn't trophy hunters, it's their lack of value to local people. In L. Butterfield (Ed.), Lion populations are at a tipping point. London: Oxford University.

Dickman A, Hazzah L, Carbone C, Durant SM (2014). Carnivores, culture and 'contagious conflict': Multiple factors influence perceived problems with carnivores in Tanzania's Ruaha landscape. Biological Conservation 178:19-27.

Gifford-Gonzalez D (2000). Animal Disease Challenges to the Emergency of Pastoralism in Sub-Saharan Africa. Archaelogical Review 17(3):95-139.

Gilioli G, Groppi M, Vesperoni M, Baumgartner J, Gutierrez A, Gilioli G (2009). An epidemiological model of East Coast Fever in African livestock. Ecological Modelling 220(13-14):1652-1662.

Hazzah L (2006). Living among lions (Panthera leo): Coexistence or killing? Community attitudes towards conservation initiatives and the motivations behind lion killing in Kenyan Maasailand. Master thesis in Conservation and sustainable development. Unpublished. University of Wisconsin-Madison pp. 1-110.

Hazzah L, Bath A, Dolrenry S, Dickman A, Frank L (2017). From attitudes to actions: Predictors of lion killing by Maasai warriors. PloS One 12(1). https://doi.org/10.1371/journal.pone.0170796.

Hodgson DL (2011). Being Maasai, Becoming Indigenous: Postcolonial Politics in a Neoliberal World. Indiana, USA: Indiana University Press.

Holdo RM, Galvin KA, Knapp E, Polasky S, Hilborn R, Holt RD (2010). Responses to alternative rainfall regimes and antipoaching in a migratory system. Ecological Applications 20(2):381-397.

Hugh-Jones ME (2014). Overview of Anthrax. Veterinary Clinical
Sciences, University of Edinburgh, Scotland.Retrieved from; https://www.msdvetmanual.com/generalized-

conditions/anthrax/overview-of-anthrax.

International Business Machines (IBM) (2016). IBM SPSS Statistics for Windows, Version 24.0. from IBM Corp, Armonk, NY, USA.

Jibbo JMC, Durkin J, Light DE, Murray M, Sones K, Trail JCM (2010). Chemoprophylaxis: Its successful use in the control of trypanosomiasis in Boran cattle, at Mkwaja Ranch, Tanzania. From FAO, Corporate Document Repository.

Kidegesho JR (2008). Who Pays for Wildlife Conservation in Tanzania and Who Benefits? Faculty of Forestry and Nature Conservation, Department of Wildlife Management, Sokoine University of Agriculture, P. O. Box 3073, Morogoro Tanzania. Retrieved from; https://hdl.handle.net/10535/587, 1-24.

Kideghesho JR, Røskaft E, Kaltenborn BP (2007). Factors influencing conservation attitudes of local people in Western Serengeti, Tanzania. Biodiversity and Conservation 16(7):2213-2230.

Kivaria $F$ (2007). The control of East Coast Fever in Africa: A constant battle for impoverished dairy farmers. Veterinary Journal 174(2): 221 222.

Lagendijk DDG, Gusset M (2008). Human-Carnivore Coexistence on Communal Land Bordering the Greater Kruger Area, South Africa. Environmental Management 42(6):971-976.

Lembo T, Hampson K, Haydon DT, Craft M, Dobson A, Dushoff J, Cleaveland S (2008). Exploring reservoir dynamics: a case study of rabies in the Serengeti ecosystem. Applied Ecology 45(4):1246-1257.

Linnell JDC, Swenson JE, Andersen R (2001). Predators and people: conservation of large carnivores is possible at high human densities if mangement policy is favourable. Animal Conservation 4(4):345-349.

Lyamuya RD, Masenga EH, Fyumagwa RD, Mwita MN, Røskaft E (2016). Pastoralist herding efficiency in dealing with carnivorelivestock conflicts in the eastern Serengeti, Tanzania. International Journal of Biodiversity Science, Ecosystem Services and Management 12(3):202-211.

Lyamuya RD, Masenga EH, Mbise FP, Fyumagwa RD, Mwita MN, Røskaft E (2014). Attitudes of Maasai pastoralist towards the conservation of large carnivores in the Loliondo Game Controlled Area of Northern Tanzania. International Journal of Biodiversity and Conservation 6(11):797-805.

Maddox TM (2003). The ecology of cheetahs and other large carnivores in a pastoralist-dominated buffer zone. (PhD thesis), University College, London and Institute of Zoology, London.

Masenga EH, Mentzel C (2005). The African wild dogs (Lycaon pictus); Preliminary results from newly established population in SerengetiNgorongoro ecosystem, northern Tanzania. Paper presented at the Proceedings of fifth annual TAWIRI scientific conference, ArushaTanzania.

Mbise FP, Jackson CR, Lyamuya R, Fyumagwa R, Ranke PS, Røskaft E (2020). Do carnivore surveys match reports of carnivore presence by pastoralists? A case of the eastern Serengeti ecosystem. Global Ecology and Conservation e01324.

Mbise FP, Skjærvø GR, Lyamuya RD, Fyumagwa RD, Jackson C, Holmern T, Røskaft E (2018). Livestock depredation by wild carnivores in the eastern Serengeti ecosystem, Tanzania. Biodiversity and Conservation 10(3):122-130.

Ministry of Natural Resources and Tourism (MNRT) (2013). The Wildlife Conservation Act (Principal Legislation). Ministry of Natural Resources and Tourism, Tanzania.

Nana ED, Tchamadeu NN (2014). Socio-economic impacts of protected areas on people living close to the Mount Cameroon National Park. Parks 20(2):129-137.

Naughton-Treves L, Grossberg R, Treves A (2003). Paying for tolerance: Rural citizens' attitudes toward wolf depredation and compensation. Conservation Biology 17(6):1500-1511.

Newmark WD, Leonard NL, Sariko HI, Gamassa DM (1993). Conservation attitudes of local people living adjacent to five protected areas in Tanzania. Biological Conservation 63(2):177-183.

Nyahongo JW, Røskaft E (2012). Assessment of Livestock Loss Factors in the Western Serengeti, Tanzania. In: A. Kaswamila (Ed.), Sustainable Natural Resources Management. InTech. pp. 156-166 https://www.intechopen.com/books/sustainable-naturalresourcesmanagement/assessment-of-livestock-loss-factors-in-the- 
western-serengeti-tanzania.

Nyhus PJT, Ronald T (2010). Panthera tigris vs Homo sapiens: Conflict, Coexistence, or Extinction. pp. 125-141 in PJ.. a. R. Tilson, editor. Tigers of the World : The Science, Politics and Conservation of Panthera tigris. Elsevier Burlington.

Redpath SM, Young J, Evely A, Adams WM, Sutherland WJ, Whitehouse A, Gutiérrez RJ (2013). Understanding and management conservation conflicts. Trends in Ecology and Evolution 28(2):100109.

Romañach SS, Lindsey PA, Woodroffe R (2007). Determinants of attitudes towards predators in central Kenya and suggestions for increasing tolerance in livestock dominated landscapes. Oryx 41(2):185-195

Scala A, Varcasia A (2006). Updates on morphobiology, epidemiology and molecular characterization of coenurosis in sheep. Parassitologia 48(1-2):61-63

Scott PR (2014). Contagious Caprine Pleuropneumonia. Veterinary Clinical Sciences, University of Edinburgh, Scotland. Retrieved from; https://www.msdvetmanual.com/respiratory-system/respiratorydiseases-of-sheep-and-goats/contagious-caprinepleuropneumonia\#v3294627.

Sharma DK, Chauhan PPS (2006). Coenurosis status in Afro-Asian region: A review. Small Ruminant Research 64(3):197-202.

Shivik JA (2006). Tools for the Edge: What's New for Conserving Carnivores. Bioscience 56(3):253-259.

Smith DW (2005). Coexisting with Large Carnivores: Lessons from Greater Yellowstone. In Clark TW, Rutherford MB, Casey D (Eds.), Living with large carnivores (pp. 290). Washington, DC: Island Press.

Smith K, De Vos V, Bryden H, Hugh-Jones ME, Klevytska A, Price L, Scholl D (1999). Meso-scale ecology of anthrax in southern Africa: a pilot study of diversity and clustering. Applied Microbiology 89(2):204207.

Spira C (2014). Large carnivores, people and livestock in the LaikipiaSamburu ecosystem: a comparative study of livestock depredation across different land-uses. (MSc. thesis in Conservation Science), Imperial College, London.
Treves A, Karanth KU (2003). Human-carnivore conflict and perspectives on carnivore management worldwide. Conservation Biology 17(6):1491-1499.

Vedeld P, Jumane A, Wapalila G, Songorwa A (2012). Protected areas, poverty and conflicts: A livelihood case study of Mikumi National Park, Tanzania. Forest Policy and Economics 21:20-31.

Woodroffe R, Thirgood S, Rabinowitz A (2005). People and Wildlife: Conflict or Coexistence? (Vol. 9). New York: Cambridge University Press. 